\title{
PENGEMBANGAN BUKU AJAR DAN BLENDED TRAINING E-FILING SYSTEM DENGAN PROGRAM IWSM DI SMKN I CIPATAT
}

\author{
Ma'mun Sutisna \\ Mamun.sutisna@polban.ac.id \\ Ii Halilah \\ ii.halilah@yahoo.com \\ Sholihati Amalia \\ liasuwardi@gmail.com \\ Sri Surjani Tjahjawati \\ sri.sujarni@polban.ac.id \\ Yayan Firmansyah \\ yayan.firmansyah@polban.ac.id \\ Irwan Setiawan \\ irwan@jtk.polban.ac.id
}

\section{POLITKNIK NEGERI BANDUNG}

\begin{abstract}
ABSTRAK
Kekurangan bahan ajar, ketidaksediaan perangkat lunak atau software dan kompetensi guru dalam menguasai bahan ajar dan cara mengajarkan materi baru berakibat pada rendahnya kualitas pembelajaran. Kondisi tersebut dialami oleh SMKN I Cipatat pada program studi Otomatisasi dan Tata Kelola Perkantoran (OTKP). Khususnya pada mata pelajaran Kearsipan bagian penerapan pengelolaan arsip elektronik Kurikulum SMK tahun 2018 revisi, Berdasarkan kebutuhan tersebut diperlukan pengembangan bahan ajar dan blended training. Tujuan kegiatan ini adalah adalah tersedianya bahan ajar atau modul dan peningkaatan kompetensi guru dalam mengoperasikan Sofftware Image ware Scan Manager (IWSM) untuk pengarsipan elektronik, merancang sistem kearsipan elektronik dan mengajarkan e-filing dengan program IWSM kepada siswa. Pada masa new normal saat ini pendekatan kegiatan Pengabdian Kepada Masyarakat perlu diadaptasi. Blended training berlangsung selama 5 hari kerja dilaksanakan 2 hari tatap muka langsung dan 3 hari secara daring via zoom meeting dan satu minggu di lapangan dengan mempertimbangkan protokol kesehatan. Hasil blended training menampilkan tingkat partisipasi partisipan dalam mengikuti blended training 97,5\%, kenaikan penguasaan modul blended training saat sebelum serta sesudahnya 122\%, dan seluruh partisipan 34 orang dinyatakan kompeten.
\end{abstract}

Kata kunci: Pengembangan Buku Ajar, E-Filing, Memaksimalkan Pengajaran, IWSM. 


\section{PENDAHULUAN}

SMKN 1 Cipatat didirikan pada tahun 2013 beralamat Jalan Terusan Cirata Km 3 Sarimukti Cipatat Kabupaten Bandung Barat Provinsi Jawa Barat memiliki program studi; Otomatisasi dan Tata Kelola Perkantoran (OTKP). Multimedia, Teknik Instalasi Listrik dan Teknik Kendaraan Ringan (TKR). Berdasarkan hasil observasi dan wawancara pada tangal 12 Febuari 2020 dan diterus dilakukan kelanjutan dengan pihak manajemen sekolah/Kepala Sekolah H.R. Dudi Rudiatna, S.Pd., S.ST., M.T. Kaprodi Otomatisasi dan Tata Kelola Perkantoran (OTKP) Ibu Desti, S.E. Dewan guru, dan siswa, mendapatkan gambaran bahwa diperlukanya bahan aja yang memumpuni, dan perangkat lunak E-filing system. Kekurangan bahan ajar, ketidaksediaan perangkat lunak atau software dan kompetensi guru dalam menguasai bahan ajar dan cara mengajarkanya, berakibat pada rendahnya kualitas pembelajaran. Jika kondisi mutu berlanjut maka kualitas lulusan juga akan rendah dalam penguasaan pengetahuan, sikap dan keterampilan yang seharusnya dikuasi. Pengabdian pada masyarakat ini akan membantu para guru-guru SMKN I Cipatat menyiapkan buku ajar atau modul mata pelajaran e-filing, software e-filing dalam rangka menambah kompetensi efiling dengan memahami sistem kerasipan elektronik Image Ware Scan Manager (IWSM).

Sejak kurikulum SMK tahun 2013 muatan teknologi informasi sudah diakomodasi, dan pada kurikulum SMK tahun 2013 edisi revisi 2017 dan revisi terakhir tahun 2018 (Perdirjen Pendidikan Dasar Dan menengah Kemendikbur : 2018) muatan tersebut ditingkatkan lagi, bahkan program keahlian Manajemen Perkantoran, keahlian Administrasi Perkantoran diubah namanya menjadi Otomatisasi dan Tata Kelola Perkantoran (OTKP). Hal ini menunjukkan bahwa kurikulum SMK selalu menyelaraskan salah satunya dengan perkembangan teknologi informasi agar lulusannya dapat diterima di lapangan pekerjaan karena memiliki kompetensi yang sesuai dengan tuntutan lapangan pekerjaan. Penelitian yang dilakukan oleh Joseph, at al (2012) mendapatkan temuan bahwa manajemen kearsipan dampaknya lebih luas untuk praktik professional.

Dalam kurikulum keahlian Otomatisasi dan Tata Kelola Perkantoran (OTKP) terdapat mata pelajaran Teknologi Perkantoran dan Kearsipan. Mata pelajaran tersebut berisi Kearsipan Manual dan Efiling atau Kearsipan Elektronik yang diberikan selama 2 semester. Mata pelajaran Teknologi Perkantoran semester 1 dan 2 masing-masing 4 jam pelajaran per minggunya atau setara dengan 72 Jam Pelajaran (JP) / semester dimana 1 JP sama dengan 45 menit. Jadi Mata pelajaran Teknologi Kantor 144 jam Pelajaran. Sedangkan Mata kuliah Kearsipan semester 1 dan 2 masing-masing 4 jam pelajaran peminggunya atau setara dengan $72 \mathrm{Jam}$ Pelajaran (JP) / semester dimana 1 JP sama dengan 45 menit. Jadi Mata pelajaran Teknologi Kantor 144 jam, jadi kedua mata pelajaran ini sebesar 288 jam pelajaran.

Dengan melihat banyaknya jam pelajaran maka kegiatan PKM ini akan sangat membantu, selain kurikulum dan proses pembelajaran yang harus selalu selaras dengan kebutuhan dunia kerja, maka guru-guru yang memfasilitasi siswa untuk mencapai kompetensi yang diharapkan pun perlu ditingkatkan kompetensinya, baik dalam bidang yang berhubungan dengan program studi tempat guru-guru tersebut mengajar maupun bidang metodologi mengajarkannya agar kompetensi yang diharapkan dapat dimiliki oleh semua lulusan dengan baik. Kompetensi e-filing yang termasuk dalam mata pelajaran Kearsipan tergolong relatif masih baru sehingga masih memerlukan blended training khusus bagi guru-guru yang mengampu mata pelajaran tersebut, baik dalam perihal kompetensi $e$ - filing-nya ataupun tata cara buat mengarahkan $e$-filing tersebut supaya siswa menggapai kompetensi yang diharapkan (Sutisna, 2020) 
Pemakaian teknologi data serta komunikasi seperti fasilitas bantu pengelolaan arsip, pada umumnya untuk tipe arsip konvensional (non- elektronik), yang buat seterusnya dinamakan dengan "otomatisasi kearsipan". Teknologi data serta komunikasi dalam perihal ini dapat digunakan untuk keperluan administrasi universal, kontrol fisik atas arsip, pengolahan serta penyajian data arsip, menemukan kembali data arsip, dan pemakaian yang lain yang berkaitan dengan penciptaan, pemeliharaan serta pemakaian, dan penyusutan arsip. Arsip elektronik ialah data yang tercantum dalam file serta media elektronik, yang dibuat diterima, ataupun dikelola oleh organisasi ataupun perorangan serta disimpan bagaikan fakta aktivitas. Ini sesuai dengan Undang-Undang No. 43 Tahun 2009, Bab III Pengalihan Bentuk Dokumen Perusahaan Dan Legalisasi, Pasal 12 Ayat 1: Dokumen perusahaan dapat dialihkan ke dalam mikrofilm atau media lainnya.

Salah satu kompetensi yang ingin dicapai dalam keahlian Otomatisasi dan Tata Kelola Perkantoran yaitu lulusannya memiliki kompetensi dalam bidang $e$ filing atau kearsipan elektronik. Kompetensi ini merupakan kompetensi yang masih relatif baru dicantumkan dalam kurikulum. Hal ini, mempengaruhi kesiapan SMK untuk mengajarkan mata pelajaran efiling tersebut, baik dari pihak guru-guru yang akan mengajarkannya maupun kesiapan sarana dan prasarana yang dibutuhkan. Dengan menggunakan metode pencarian terpadu yang sesuai dengan jenis dokumen, pengguna dapat secara mudah menampilkan dokumen yang dituju walaupun secara fisik dokumen atau arsip tersebut berada pada tempat lain Widhi, (2014)

Dalam pendidikan vokasi, seorang guru harus memiliki keahlian atau kompetensi yang dibuktikan dengan sertifikat kompetensi dari lembaga terpercaya pada bidang yang sesuai dengan mata pelajaran yang diajarkannya. Suatu kompetensi hanya dapat diajarkan oleh guru yang kompeten di bidangnya. Selain itu juga, guru harus memiliki cara atau metode yang tepat untuk mengajarkan kompetensi tersebut.

Sehubungan dengan masih barunya kompetensi tersebut, maka guru-guru yang mendapat tugas untuk mengajarkan kompetensi itu dituntut untuk memiliki kompetensi tersebut. Cara untuk mendapatkan kompetensi itu dengan melalui blended training dan atau mengikuti sertifikasi kompetensi. Dan ini, memerlukan waktu dan dana yang cukup. Namun pada kenyataannya, masih banyak guru-guru yang masih belum siap sepenuhnya untuk mengajarkan kompetensi $e$-filing karena mungkin belum memiliki kesempatan untuk mengikuti blended training atau sertifikasi kompetensi. Hal ini, mengakibatkan kurang maksimalnya pengajaran e-filing sehingga kompetensi e-filing lulusan belum maksimal. Kompetensi akan dicapai dengan maksimal bila diajarkan oleh pengajar yang kompeten dibidangnya dan dengan cara atau metode pengajaran yang tepat.

\section{METODOLOGI PELAKSANAAN}

Pengembangan Buku Ajar Dan Blended Training E-Filing System Dengan Program IWSM Di SMKN I Cipatat, membutuhkan berbagai persiapan yang wajib dipersiapkan oleh guru, instruktur dan penyelenggara blended training. Dalam blended training ini memiliki tujuan akhir tersedianya buku atas atau modul e-filing SMK, tersedianya software e-filing untuk digunakan di SMK dan meningkatnya kompetensi guru-guru SMKN I Cipatat khsusnya Program Keahlian Otomasi dan Tatakelola Perkantoran (OTKP) dalam menggunakan IWMS, merancang dan mengimplementasikan proyek EFS dan mengajarkan EFS/e-filing ke siswa SMK.

Metode pengembangan buku ajar sebagai berikut : 1. Membuat rancangan naskah/kerangka buku terdiri dari 12 bab. 2 . Memulai proses menulis dari bab ke bab 3 . Penyuntingan atau revisi 4. Percetakan atau penerbitan buku ajar. Selanjutnya berikut 
ini gambar blended training EFS sebagai berikut :

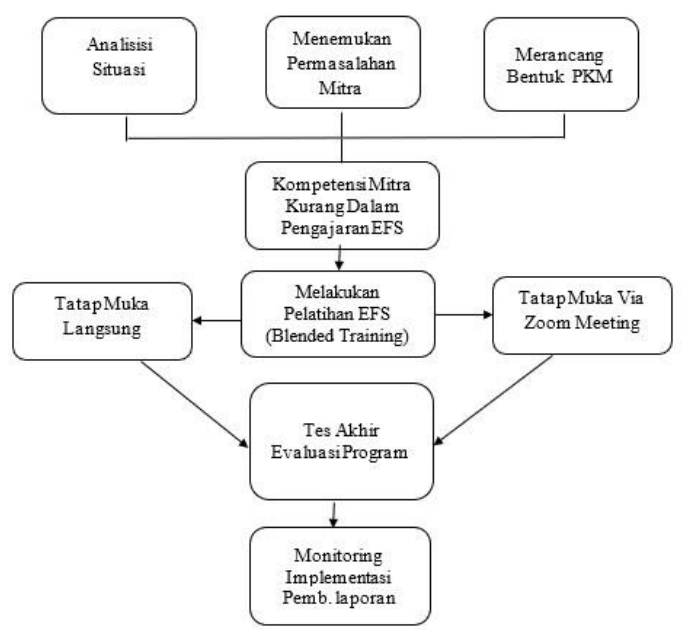

Gambar 1. Kerangka Pemecahan Permasalahan Blended Training EFS

Pada gambar 1 pelaksanaan blended training EFS secara rinci ditempuh melalui mekanisme sebagai berikut :

Metode pelaksanaan blended training EFS ditempuh melalui mekanisme sebagai berikut :

1) Melakukan survey awal penjajakan, observasi dan wawancara lapangan dengan mitra kemudian merancang kegiatan dan Metodologi blended training.

2) Mendapat temuan kompetensi guru SMKN I Cipatat dalam EFS kurang dikarenakan mata pelajaran relative baru.

3) Pelaksanaan blended training EFS selama 5 hari sesuai jadwal dilakukan secara Blended Training yaitu tatap muka langsung, Zoom meeting dan $e$ learning dengan WA disesuaikan dengan masa New Normal Pandemi Covid-19 Zona Hijau. Hari 1 blended training tatap muka langsung dengan kegitan Pendaftaran, Pembukaan, Tes Awal, Orientasi Program Blended training, Pengantar Pengelolaan Arsip Elektronik, Pengenalan Software EFiling Scan Manager, Install program, Pengenalan operasi dasar IWSM dan Membuat Lemari Virtual penyimpanan dokumen (Work Group). Hari ke kedua dan hari ke 3 blended training dilakukan secara tatap muka virtual dengan Zoom Meeting, sesuai dengan jawal. Hari ke 4 Partisipan dikelompokan menjadi 2 grup mempraktikan hasil blended training dengan membuat proyek penanganan arsip. Grup 1 di SMKN Cipatat dan Grup 2 di perusahaan di bawah bimbingan instruktur. Hari ke 5 melakukan review dan latihan bagian yang belum mahir, melakukan presentasi proyek, melakukan tes akhir penguasaan EFS dan mengajarkannya. Blended training ditutup dengan evaluasi program dengan menggunakan google form, penutupan dan poto bersama.

4) Melakukan monitoring Implementasi Hasil Blended training pada pembelajaran Mata Pelajaran e-filing di SMK Mitra.

5) Membuat Laporan Pelaksanaan Kegiatan.

Penilaian yang akan dilakukan dalam pelaksanaan blended training EFS ini ada dua cara, yaitu :

a. Penilaian di awal blended training

(Pre-test)

Pretest diberikan kepada para partisipasi untuk mengetahui keahlian awal, paling utama pemahaman serta pemahaman tentang manajemen kearsipan dan e-filing secara umum. Hasil penilaian, menjadi masukan untuk posisi awal pemberian materi agar materi yang disampaikan dapat sesuai dengan pemahaman awal partisipan.

b. Penilaian di akhir blended training

(Postest)

Untuk penilaian akhir blended training, dilakukan buat mengenali keahlian serta keahlian partisipan sepanjang blended training. Penilaian ini terdiri dari dua kegiatan, yaitu penilaian pada aspek kemampuan penggunaan Software Image Ware Scan Manager, penilaian tentang proyek 
rancangan EFS dan Cara Mengajarkan EFS kepada siswa.

Indikator keberhasilan dari kegiatan ini ditandai dengan :

- Partisipan blended training mempunyai pengetahuan manajemen Kersipan secara digital/elektronik.

- Partisipan blended training mempunyai pengetahuan tentang software Image Scan Manager.

- Partisipan blended training mempunyai pengetahuan tentang perancangan sistem e-filing.

- Partisipan blended training mampu untuk melakukan instalasi program EFS.

- Partisipan blended training mampu untuk melakukan manajemen kearsipan sesuai dengan menggunakan program IWMS mata pelajaran e-filing.

- Partisipan blended training mampu membuat Work Group, Worksheet Template, Worksheet, membuat user name dan password.

- Partisipan blended training mampu melakukan impor dan ekspor dokumen, mengindeks dokumen.

- Partisipan blended training mampu melakukan indeks, menemukan dan mencetak dokumen yang diperlukan.

- Penilaian dilakukan baik sebelum dan sesudah blended training (Pre dan Post-Test). Indikator capaian keberhasilan blended training dilihat dari 3 aspek ialah: kedatangan rata- rata $80 \%$, kenaikan kemampuan modul dari saat sebelum serta setelah blended training $\geq 75 \% \quad$ serta jumlah Partisipan yang kompeten $\geq 80 \%$. Hasil penilaian penguasaan materi blended training dibagi 3 grade, yaitu Kompeten apabila Nilai $>80$; Cukup Kompeten $71-80$, dan tidak lulus $<71$.
Pada pelaksanaan blended training, peran serta mahasiswa sangat dibutuhkan buat mendukung keberhasilan aktivitas blended training serta buat membantu yang berkaitan dengan hal teknis blended training. Mahasiswa beserta kedudukan kegiatannya dalam aktivitas PKM ini. Mahasiswa Jurusan Administrasi Niaga Program Studi D3 Administrasi Bisnis Polban, mempunyai peran membantu partisipan blended training bila ada yang membutuhkan bantuan teknis penggunaan software EFS. Pelaksanaan Program Pengabdian Masyarakat Pengembangan Buku Ajar Dan Peningkatan Kompetensi EFiling Untuk Memaksimalkan Pengajaran E-Filing Dengan Program Image Ware Scan Manager (IWSM) Di SMKN I Cipatat", dilaksanakan tanggal 4 hingga 8 Agustus 2020. dihadiri oleh 34 orang Partisipan. Tempat Pelaksanaan kegiatan PKM EFS berupa Pengembangan buku ajar/modul -efiling dan Blended training di SMKN I Cipatat dan Politeknik Negeri Bandung Via Zoom Meeting, Jl. Gegerkalong Hilir, Ciwaruga, Kecamatan Parongpong, Kabupaten Bandung Barat

\section{HASIL DAN LUARAN}

Secara umum pengembangan buku ajar dan blended training EFS ini dapat berjalan dengan baik, berikut hasil cover buku ajar EFS yang dihasilkan pada Gambar 2 seperti berikut ini:

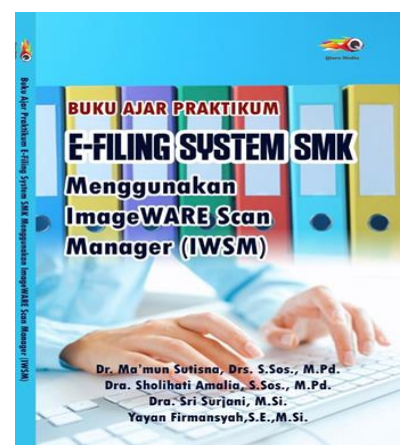

Gambar 2. Cover Buku Ajar Praktikum EFiling System SMK Menggunakan IWMS

Pada gambar 2 pengembangan buku ajar praktikum E-Filing System SMK menggunakan IWMS telah diterbitkan oleh penerbit Qiara Media, buku ini juga telah 
mendapatkan HAKI dengan nomor 000207209. Buku ini dapat menjadi bahan ajar mata pelajaran EFS SMK. Selanjutnya hasil secara rinci blended training EFS sebagai berikut:

\subsection{Jumlah Dan Keberhasilan Partisipan} Blended Training

Pada tabel berikut mencantumkan jumlah Partisipan blended training baik yang sifatnya daring dan luring pada Tabel 3.1 sebagai berikut :

Tabel 3.1. Jumlah dan Jenis kelamin Partisipan

\begin{tabular}{|c|l|r|c|}
\hline No & $\begin{array}{l}\text { Jenis } \\
\text { Kelamin }\end{array}$ & Jumlah & $\begin{array}{c}\text { Persentas } \\
\text { e (\%) }\end{array}$ \\
\hline 1 & Perempuan & 18 & 55 \\
\hline 2 & Laki-Laki & 16 & 45 \\
\hline & Total & 34 & 100 \\
\hline
\end{tabular}

Tabel 2.1 manunjukkan jumlah Partisipan berjumlah 34 orang terdiri dari $55 \%$ Partisipan perempuan dan $45 \%$ Partisipan laki-laki. Semulan Partisipan direncanakan 30 orang, namun animo guru-guru untuk mengikuti blended training sangat tinggi sehingga menjadi 34 orang. Berikutnya tabel 3.2 menjelaskan tentang porsentasi kehadiran, sebagai berikut:

Tabel 3.2. Kehadiran Partisipan

\begin{tabular}{|l|r|l|c|}
\hline No & $\begin{array}{c}\text { Jenis } \\
\text { Kelamin }\end{array}$ & Jumlah & $\begin{array}{l}\text { Persentase } \\
(\%)\end{array}$ \\
\hline 1 & Perempuan & 18 & 100 \\
\hline 2 & Laki-Laki & 16 & 95 \\
\hline & Total & 348 & 97,5 \\
\hline
\end{tabular}

Tabel 3.2 manunjukkan Rata-rata kehadiran peseerta adalah 97,5\%. Kehadiran Partisipan Partisipan perempuan dan $100 \%$ dan Partisipan laki-laki 95\%.

3.3 Pencapaian Kualifikasi Kompetensi

Penguasaan Materi Blended training
Pada sub bab ini kita melihat kompetensi akhir partisipan blended training, seperti Tabel 3.4 sebagai berikut :

Tabel 3.4. Pencapaian Kompetensi Akhir Blended training

\begin{tabular}{|c|c|c|c|}
\hline $\begin{array}{l}\mathbf{N} \\
\mathbf{0}\end{array}$ & $\begin{array}{c}\text { Capaian } \\
\text { Kualifikasi } \\
\text { Kompetens } \\
\text { i } \\
\text { Akhir } \\
\text { Blended } \\
\text { training }\end{array}$ & $\begin{array}{l}\text { Jumla } \\
\text { h }\end{array}$ & $\begin{array}{l}\text { Persentas } \\
\text { e }(\%)\end{array}$ \\
\hline 1 & Kompeten & 34 & 100 \\
\hline 2 & $\begin{array}{l}\text { Cukup } \\
\text { Kompeten }\end{array}$ & 0 & 0 \\
\hline & Total & 34 & 100 \\
\hline
\end{tabular}

Tabel 3.4 menunjukkan bahwa dilihat dari kualifikasi kompetensi dari hasil blended training sebanyak 34 orang Partisipan 100\% kompeten. Berdasarkan kriteria jumlah Partisipan memiliki kualifikasi penguasaan juga berhasil $100 \%>80 \%$.

3.4. Pembahasan

Pada kegiatan pengabdian pada umumnya berjalan lancar, dimulai dari aktivitas survey pendahuluan, observasi dan wawancara untuk analisis situasi, pelaksanaan kegiatan pengabdian pada masyarakat kepada penyusunan laporan. Berdasarkan diskusi yang dilakukan Tim instruktur Blended training dan Partisipan blended training diperoleh kesimpulan bahwa blended training berjalan lancar. Indikator lancarnya kegiatan ini terlihat dari antusias dalam proses blended training seperti tingkat kedatangan partisipan, aktifnya dikala berdiskusi, frekuensi pertanyaan tinggi. Materi yang disampaikan dan minta diulang untuk diberi contoh pada saat sesi tanya-jawab kepada tim instruktur dan saat praktik sampe lupa waktu istirahat. Nampaknya partisipan menyadari pentingnya blended training ini untuk memperoleh kompetensi yang dibutuhkan diera digital. e-filing merupakan salah satu penunjang dalam melakukan manajemen kearsipan secara digital atau otomatis. 
Melalui pengabdian masyakarat yang berkelanjutan sesuai road map yang sudah dibuat akan terjalin hubungan kerjasama antara program studi Administrasi Bisnis Polban dengan guru-guru SMKN I Cipatat khusunya Program Keahlian Otomasi dan tatakelopa perkantoran (OTKP). Hubungan kerjasama dalam hal pengembangan sistem pengarsipan elektronik atau $e$-filing dengan memodifikasi menjadi aplikasi yang lebih murah dan cepat. Selain itu metode pembelajarannya bagi guru dan staf TU sehingga program pengabdian kepada masyarakat dapat berjalan maksimal.

Secara keseluruhan hasil kegiatan blended training Pengembangan Buku Ajar Dan blended taining E-Filing agar mengoptimalkan pengajaran E-Filing dengan Program Image Ware Scan Manager (IWSM) Di SMKN I Cipatat ini berlangsung dengan baik, karena telah sesuai dengan rencana pada proposal yang diajukan. Keikutsertaan Partisipan yang diundang sebanyak 30 orang, bertambah peminatnya menjadi 34 orang, atau $100 \%$, dan rata-rata kehadiran mengikuti blended training sebesar 97,5\%.

Pelaksanaan blended training dilakukan secara Blended Training, yaitu menggunakan kombinasi tatap muka langsung dengan tatap muka via cetak zoom meeting, sesuai masa new normal pandemi covid-19 di zona hijau. Pada dasarnya dua aktivitas blended training tatap muka langsung maupun via zoom meeting sama, Partisipan bisa langsung melihat langsung penyajian instruktur, bisa tanya jawab, bisa meminta pengulangan, dan latihan secara terkontrol oleh instruktur, dan melakukan tutorial untuk konsultasi, Partisipan bisa menunjukkan atau mepresentasikan hasil pekerjaannya secara daring, tetapi yang membedakannya jarak dan sifatnya maya. Pada saat proses daring tatap muka via zoom meeting sangat lancar dan terkendali, karena penyelenggara menggunakan platform zoom meeting berbayar, sehingga tidak terkendala dalam pelatihannya. Demikian juga Partisipan tidak menemukan kendala, karena diberi bantuan kuota internet
Telkomsel kurang lebih 8 giga tiap Partisipan.

Dalam proses penerapan aktivitas blended training, tiap- tiap Partisipan memakai 1 fitur pc (personal computer) di SMKN/laptop masing-masing yang terleih dahulu diinstal software IWSM, diberikan modul atau buku ajar $e$-filing materi blended training, power point dan video tutorial penggunaan program $e$-filing. Dengan cara 1 partisipan 1 pc dengan materi yang dirancang scara step by step pengoperasian program dan video turorial, sehingga memungkinkan partisipan buat belajar sambil mengaplikasikan. Penyampaian materi blended training tatap muka langsung dilakukan dengan bantuan LCD Proyektor, sehingga proses komunikasi bisa berlangsung dengan baik, paling utama pada dikala penyampaian modul yang berbentuk bimbingan step- by- step, sedangkan pada saat daring tiap Partisipan bisa memonitor di presentasi dan latihan di layar monitor masing-masing.

Pada penilaian pelaksanaan dan hasil blanded training dilakukan dengan tahapan:

a. Tiap tahapan aktivitas( masing- masing topik) dicoba evaluasi terhadap keahlian Partisipan serta hasilnya dikonfirmasikan kepada Partisipan.

b. Partisipan dimohon melakukan aplikasi serta simulasi dari masing- masing topik lewat aktivitas workshop.

c. Partisipan dimohon melakukan aplikasi merancang kearsipan elektronik di laboratorium, serta membuat projek perancangan kearsipan elektronik secara berkelompok.

Evaluasi dicoba uji awal serta uji akhir. Uji awal dicoba buat mengenali keahlian awal dari partisipan terhadap modul blended training yang hendak dicoba.

Modul uji ialah garis besar ataupun mewakili segala modul blended training baik yang bersifat penerapan ataupun yang bersifat teori. Dari hasil yang dicapai oleh partisipan blended training disaat uji awal skor rata- rata ialah 38,7 . Uji akhir dicoba buat mengenali pencapaian kompetensi sesudah mengikuti blended training. Hasil 
evaluasi blended training diperoleh nilai rata- rata 86,1 , sehingga delta uji awal serta akhir sebesar 47, 4 ataupun $122 \%$. Maksudnya penerapan blended training bisa dikategorikan berjalan dengan baik serta hasilnya sangat memuaskan. Dilihat dari jumlah Partisipan yang meraih kualifikasi kompeten sebanyak 100\% ataupun 34 orang. Artinya blended training sukses meraih sasaran dari blended training yaitu seluruh Partisipan blended training memahami modul blended training.

Dari aspek penyelenggaraan, komponen- komponen yang dievaluasi merupakan modul blended training, proses blended training, faslitator, dan kelancaran penerapan blended training secara totalitas yang dinilai oleh Partisipan lewat kuesioner, hasilnya sangat baik ialah 93, 25\%.

Hasil kusioner penilaian program kepada Partisipan, serta respon yang kami peroleh sebagai berikut:

1. Materi yang diberikan cukup memadai $88,18 \%$ menyatakan dilihat dari segi mutu dan kuantitas. Isi modul cukup aplikatif, rinci, menarik, serta mudah dipahami.

2. Penyampaian materi oleh fasilitator dinilai 96,14\% menyatakan ini berarti sangat baik. Begitu pula dengan para pengajar/ fasilitator sanggup melakukan peranannya dengan sangat baik serta senantiasa berupaya buat membuat kelas dalam kondisi dinamis.

3. Fasilitator memperlihatkan pengetahuan pada areanya $93,45 \%$ menyatakan sangat baik.

4. Para Partisipan dirasakan 93,52\% menyatakan sangat positif, sehingga lebih mendorong terciptanya kondisi yang menyenangkan.

5. Sumber belajar $92,14 \%$ menyatakan baik dan mudah untuk dibaca, dipelajari dan diaplikasikan.

6. Hampir seluruh Partisipan memberi komentar menginginkan waktu blended training agar diperpanjang dengan tatap muka langsung, dan praktik disarankan lebih banyak..
7. Hampir seluruh partisipan berminat buat mengikuti kembali blended training sejenis dengan pendalaman sebagian topik secara khusus yang terdapat dalam blended training ini.

8. Seluruh Partisipan menyatakan sangat manfaat bagi Partisipan yang mengikuti blended training ini, baik bagi prodi maupun tempat bekerja

9. Hampir seluruh peserrta blended training ini memperhatikan protocol kesehatan Covid-19, dengan menggunakan masker dan jaga jarak.

Kegiatan blended training berjalan lancar selama 5 hari blended training dua hari tatap muka langsung dan 3 hari daring melalui zoom meeting yang dihadiri 34 orang. Kegiatan dari awal hingga akhir acara Partisipan mengikuti dengan baik tanpa ada Partisipan yang membolos pada saat blended training.

Para Partisipan sangat antusias mengikuti kegiatan pengabdian ini baik ketika tatap muka langsung maupun daring, karena melalui kegiatan ini Partisipan tidak hanya mempelajari materi mengenai $e$ filing, Partisipan juga melakukan praktik merancang proyek e-filing dan mengajarkannya. Kegiatan tersebut sangat membantu Partisipan sebagai tenaga pengajar dan tata usaha di SMKN I Cipatat dalam memberikan materi pelajaran $e$ filing sebagai bagian dari mata pelajaran manajemen kearsipan di bidang keahlian Otomasi dan Tatakelola Perkantoan (OTKP). Para partisipan sangat aktif dalam diskusi dan bertanya kepada tim fasilitator terhadap modul-modul yang disampaikan.

Materi yang diberikan pada blended training sangat sesuai dengan kebutuhan Partisipan sebagai guru Sekolah Menengah Kejuruan (SMK) terutama bidang keahlian Otomasi dan Tatakelola Perkantoran (OTKP). Partisipan blended training memiliki kewajiban yang harus ditunaikan yaitu meningkatkan kompetensi guru bidang keahlian khususnya keahilian penggunaan $e$-filing dan metodologi pengajaran e-filing agar mampu mengantarkan para siswa untuk mencapai kompetensi tertentu bidang EFS 
yang dituntut di dunia kerja. Penguasaan Mata Pelajaran Kearsipan Manual dan EFilling (kearsipan elektronik) oleh para siswa meningkatkan kemampuan siswa dalam melaksanakan satu tugas spesifik, menggunakan alat dan informasi, dan prosedur kerja yang lazim dilakukan, serta menunjukkan kinerja dengan mutu yang terukur, di bawah pengawasan langsung atasannya dalam bidang pengelolaan arsip baik manual maupun elektronik. Dalam artian mencapai Kerangka Kompetensi Nasional Indonesia (KKNI) Level 2.

Kegiatan pengabdian pada masyarakat mengenai "Pengembangan Buku Ajar Dan Blended Training E-Filing Dengan Program Image Ware Scan Manager (IWSM) Di SMKN I Cipatat", berjalan dengan lancar. Akan tetapi terdapat beberapa hambatan yang berarti. Pemaparan materi harus dilakukan dengan cepat mengingat waktu blended training yang sangat singkat, hanya 5 hari, dengan mengombinasikan teori dan praktik langsung baik tatap muka langsung maupun daring dan Praktik Lapangan di Instansi SMKN I Cipatat dan Perusahan sekitar SMK. Berikut kami sertakan beberapa foto kegiatan Pengabdian Kepada Masyarakat yang telah terselenggara, sebagai berikut:

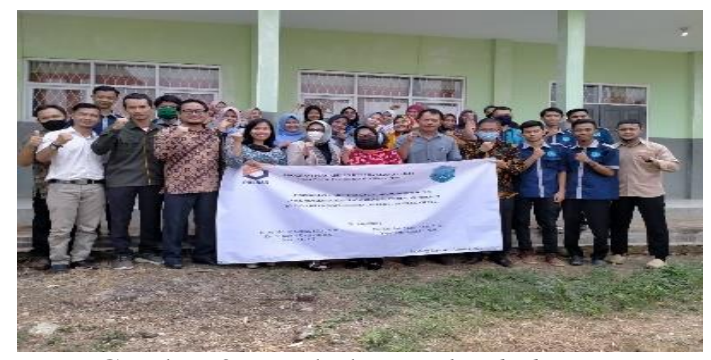

Gambar 3. Pembukaan Blended training secara Tatap Muka

Gambar tiga di atas merupakan foto pembukaan blended training klasikal atau tatap muka, semua narasumber dan peserta foto bersama.

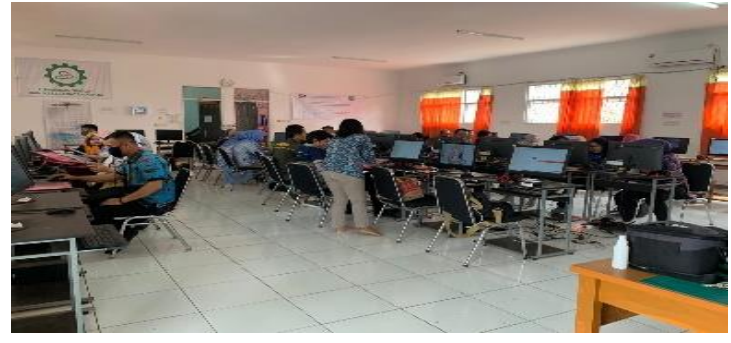

Gambar 4. Pelaksanaan Blended training Tatap Muka

Pada Gambar 4 suasana blended training tatap muka di laboratorium multimedia SMKN I Cipatat.

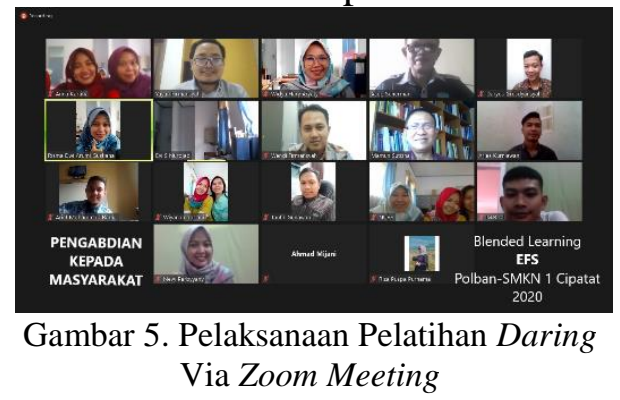

Pada gambar 5 susana blended training saat daring menggunakan aplikasi Zoom premium yang dilakukan selama 3 hari.

\section{KESIMPULAN}

1. Bahan ajar atau modul $e$-filing sudah tersusun dan dapat digunakan di SMKN I Cipatat untuk siswa program keahlian OTKP.

2. Software e-filing sudah diberikan dan digunakan dalam pelaksanaan blended training e-filing ini.

3. Kegiatan pengabdian pada masyarakat berupa pengembangan buku ajardan blended training e-filing dapat dikategorikan berhasil dari segi partisipasi. Partisipan yang semula 30 orang masih nambah menjadi 34 orang Partisipan dan hadir hampir 100\% sampai akhir program.

4. Kemampuan/ kompetensi guru-guru Sekolah Menengah Kejuruan(SMKN I) Cipatat dalam mengunakan atau mengoperasikan software IWSM, merancang proyek e-filing mengajarkannya sangat baik, dilihat dari nilai penguasaan materi sebelum dan sesudah blended training dan 
Partisipan blended training yang mencapai tingkat kompeten.

5. Partisipan blended training mendapatkan manfaat kegiatan pengabdian kepada masyarakat, terutama pengajar program Studi OTKP (Otomasi dan Tata Kelola Perkantoan). Mereka menyatakan perlu untuk mengembangkan kemampuan $e$-filing sebagai bagian dari manajemen kearsipan. Blended training e-filing ini dapat membantu pengajar SMK dalam mengajakan manajemen kearsipan secara elektronik dengan menggunakan teknologi informasi/digital e-filing sehingga mampu madukan pembelajaran manajemen kearsipan melalui digital dan manual (konvensional) sehingga dapat saling melengkapi.

6. Partisipan blended training menyatakan kegiatan pengabdian kepada masyarakat yang dilaksanakan memiliki kualitas pemateri, kualitas bahan ajar sangat baik. Partisipan pula melaporkan sangat mengerti atas uraian yang sudah diberikan oleh instruktur pengabdian dan terampil menggunakan software IWSM. Hal ini dapat terlihat dari hasil angket atas persepsi Partisipan terhadap peningkatan pemahaman yang menyatkan sangat paham.

7. Partisipan merasa dengan pengalaman baru dalam proses belajar-mengajar $e$ filing, maka diharapkan dapat menyipakan siswa sebelum lulus dengan kompetensi pengelolaan kearsipan dengan sistem digital, sehingga dapat meningkatkan relevansi antara pembelajaran di SMK dengan kebutuhan kompetensi di lapangan.

\section{SARAN}

1. Program Pengabdian Kepada Masyarakat terkait blended training e-filing hendaknya dilakukan
2. Para Partisipan blended training menerapkan ilmu dan pengetahuan yang telah didapatkan melalui

3. Pemanfaatan media daring-zoom meeting dalam blended training dapat digunakan dalam blended training berikutnya karena terbukti efektif, dengan paltform berbayar filing.

\section{UCAPAN TERIMAKASIH}

Program Pengabdian pada masyarakat Politeknik Negeri Bandung dengan judul Pengembangan Buku Ajar Dan Blended Training E-Filing System Dengan Program IWSM Di SMKN I Cipatat terlaksana dengan lancar. Tujuan dan target dari pelaksanaan pengabdian kepada masyarakat dapat dicapai. Syukur Alhamdulilah dipanjatkan kepada Tuhan Yang Maha Esa atas rahmat dan karuniaNya sehingga kegiatan ini berjalan lancar. Pada kesempatan ini tim Pengabdian pada Masyarakat menyampaikan terima kasih serta penghargaan kepada:

1. Kepala PPPM Politeknik Negeri Bandung serta jajarannya atas fasilitas kegiatan pengabdian kepada masyarakat ini.

2. Pimpinan Jurusan Administrasi Niaga serta Jajarannya, rekan-rekan dosen sebagai tim Pengabdian, laboran dan mahasiswa sebagai tutor blended training yang sudah bekerja sama untuk mewujudkan kegiatan ini.

3. Kepala sekolah Menengah Kejuruan Negeri (SMKN 1) Cipatat serta jajaran. guru-guru khususnya dewan guru berserta staf tata usaha partisipan blended training yang blended training sampai tuntas.

\section{DAFTAR PUSTAKA}

Joseph, P. at al (2012). Paradigm shifts in recordkeeping responsibilities: implications for ISO 15489's implementation. Records Management Journal. Vol. 22 No. 1, 2012 pp. 57-75 q Emerald Group 
Publishing Limited 0956-5698 DOI

10.1108/09565691211222108.

Peraturan Dirjen Pendidikan Dasar dan

Menangah Kementrian Pendidikan

dan Kebudayaan Nomor:

07/D.D5/KK/2018.1

Sutisna, M. (2020) Pengembangan

Pembelajaran Kearsipan Melalui

Blended Training Electronic Filing

System (EFS) dengan Program IWSM

di Sekolah Menengah Kejuruan

(SMK) Jurnal Abdimas-Polibatam, Vol. 2, No. 1.

Undang-undang Republik Indonesia Nomor 43 Tahun 2009 Tentang Kearsipan.

Widhi, S H. (2014). Modul Pemasaran Jasa Kearsipan. Universitas Terbuka. 